\title{
Virus Incidence Associated with Native Potato Yield in Microcenters of Potato Genetic Diversity of Bolivian
}

\author{
Mario Coca Morante ${ }^{1}$ - Evelyn Coca Salazar ${ }^{2}$ Javier Burgos Villegas ${ }^{3} \cdot$ Nelson Tapia Ponce $^{4}$
}

Accepted: 13 September 2021 / Published online: 16 October 2021

(c) The Author(s) 2021

\begin{abstract}
In the Bolivian Andean region, a diversity native potatoes species (Solanum spp) are cultivated. Areas where many types of native potato are grown are known as microcentres of potato genetic diversity. However, yields are low in these places, apparently related to viral infections. The incidence of the potato-affecting viruses Potato Virus $X$ (PVX), Potato Virus $Y$ (PVY), Potato Leaf Roll Virus (PLRV), Andean Potato Latent Virus (APLV) and Andean Potato Mottle Virus (APMoV) was examined by DAS-ELISA in microcentres of two high Andean regions of Bolivia, i.e. an Aymara culture region in the north of La Paz, and a Quechua culture region in the Dept. of Cochabamba. The relationship between viral incidence and potato yield was explored as well. The presence of all five viruses was detected in both regions, except APMoV in the Aymara region. The mean overall incidence of viral infection was greater in the Aymara than in the Quechua region. The most commonly detected viruses were PVX, PVY and APLV. Mix-infections of PVY + PVX and PVY + PLRV were most common in the Aymara region, and PVX + APLV and PVX + APMoV in the Quechua region. Potato yield was less in Aymara than in Quechua region and it was correlated to higher incidence of PVY and PVX in Aymara region. Low yields and high incidence of viral infection seems to be related to the ancestral management by planting native seed potatoes of poor quality. In conclusion, four of the five viruses sought were detected in the Aymara region, and all five in the Quechua region, although the overall incidence of viral infection was greater in the Aymara region, where the yields recorded were also lower.

Resumen.

En la región andina boliviana se cultivan una diversidad de especies nativas de papa (Solanum spp). Las áreas donde se cultivan muchos tipos de papa nativa se conocen como microcentros de diversidad genética de la papa. Sin embargo, los rendimientos son bajos en estos lugares, aparentemente relacionados con infecciones virales. Se examinó la incidencia de los virus que afectan a la papa, el Virus X de la Papa (PVX), Virus Y de la Papa (PVY), Virus del Rollo de hoja de Papa (PLRV), Virus Latente de la Papa Andina (APLV) y Virus moteado de la Papa Andina(APMoV) por DAS-ELISA en microcentros de dos regiones altoandinas de Bolivia, por ejemplo, una región de cultivo Aymara en el norte de La Paz y una región de cultivo Quechua en el Departamento de Cochabamba. También se exploró la relación entre la incidencia viral y el rendimiento de la papa. Se detectó la presencia de los cinco virus en ambas regiones, excepto APMoV en la región Aymara. La incidencia global media de infección viral fue mayor en la región Aymara que en la región Quechua. Los virus más comúnmente detectados fueron PVX, PVY y APLV. Las infecciones por mezcla de PVY + PVX y PVY + PLRV fueron más comunes en la región Aymara, y PVX + APLV y PVX + APMoV en la región Quechua. El rendimiento de papa fue menor enAaymara que en la región Quechua y se correlacionó con una mayor incidencia de PVY y PVX en la región Aymara. Estamos evidenciando que los bajos rendimientos y la alta incidencia de infección viral parecen estar relacionados con el manejo ancestral mediante la siembra de papas de semilla nativa de mala calidad. En conclusión, cuatro de los cinco virus buscados se detectaron en la región Aymara, y los cinco en la región Quechua, aunque la incidencia general de infección viral fue mayor en la región Aymara, donde los rendimientos registrados también fueron menores.
\end{abstract}

Keywords Yield reduction $\cdot$ Native potatoes $\cdot$ Potato viruses $\cdot$ Traditional agriculture

Mario Coca Morante

m.cocamorante@umss.edu.bo

Extended author information available on the last page of the article 


\section{Introduction}

The potato (Solanum tuberosum L.) is a traditional crop of the Bolivian High Andes. Several native potato species and varieties are cultivated, such as Solanum tuberosum subsp. andigena (Juzepczuk et Bukasov) Hawkes, Solanum stenotonum Juzepczuk et Bukasov, Solanum phureja Juzepczuk et Bukasov, Solanum x juzepzukii Bukasov, Solanum curtilobum Juzepczuk et Bukasov, Solanum $\mathrm{x}$ chaucha Juzepczuk et Bukasov, and Solanum x ajanhuiri Juzepczuk et Bukasov.

The regions of traditional Aymara and Quechua culture are those where native potatoes are commonly cultivated. Within these regions there are certain areas where many native potato types are grown; these areas are known as microcentres of potato genetic diversity (MPGD) (Terrazas et al., 2005; Iriarte et al., 2009, Coca Morante, 2019). Unfortunately, native potato types are being lost in these microcentres since their yields are historically low compared to those of better quality of seed tubers (as the "Huaych'a" selected native variety and Desiree introduced variety). In 1954, it was reported that the yields of 120 native potato varieties of the Bolivian Altiplano ranged from 1 to 7 t.ha ${ }^{-1}$, with 91 of these yielding between 1 and 5 (Rodríguez, 1954). According to Rodriguez (1954), these low yields were a consequence of "degenerative" diseases caused by viruses. Currently, average yields are just 5.5 t.ha $^{-1}$ (FAO 2008) perhaps because smallholders often use low quality seed potatoes (locally known as "tired seed") derived from their ancient crop varietiesvarieties that have long been affected by viruses.

Certainly, Bertschinger et al. (1990) indicated one of the most important causes of seed potato 'degeneration' to be the viral infection of potato tubers. The term degenerative was also applied to viral diseases in potato by Bokx (1972). More specifically, Quenouille et al. (2013) reports Potato virus $Y$ (PVY) to have first been associated with a disease causing potato 'degeneration' in the early 1930s.

More than 50 different viruses and one viroid have now been reported to infect potatoes around the world but a handful of them cause major losses worldwide, while some are locally and/or temporarily important. Others currently cause few concerns anywhere (Potato black ringspot virus, PBRSV; Potato virus U, PVU; Cherry leaf roll virus, CLRV; etc.) but PVY and PLRV are now the most damaging viruses of potato worldwide (Kreuze et al., 2020). PVY, however, with its worldwide distribution and notable economic impact, is one of the 10 most important cropplant viruses, (Scholthof et al., 2011; Lacomme and Jacquot 20172017). According to Kreuze et al. (2020), PVY (especially) and Potato leaf roll virus (PLRV) are now the most damaging of all potato-infecting viruses; either type can cause important yield losses, but when in combination with other viruses losses can exceed $80 \%$. Potato virus $X$ (PVX) also occurs commonly worldwide and can cause losses of $10-40 \%$, and even more when infection occurs in combination with PVY or Potato virus A (PVA); on the other hand, en the Peruvian highlands, ELISA-based surveys have been conducted since the 1980s to detect the most common potato viruses (PVY, PVX, Potato virus $S$ [PVS], PLRV, Andean potato mottle virus (APMoV) and Andean potato latent virus (APLV) in plants growing at high altitude $(>3000 \mathrm{~m})$. The most frequently detected viruses are those that are contact-transmitted, with PVX (incidence 30-82\%) and PVS (20-50\%) the most common, followed by APMoV (4-15\%) and APLV (2-6\%) (Kreuze et al., 2020). ELISA testing performed in the Cochabamba high Andes region (2900-3380 m) of Bolivia in 1992 showed the most common viruses affecting the Huaych'a (Solanum andigena L.) native variety to be PVX, APLV, APMoV and PVY, and to a lesser extent PVS and PLRV (Garcia and Gandarillas, 1992). The aim of the present work was to provide an update of the incidence of the five potato viruses in MPGDs of two high Andean regions of Bolivia, and to examine their association with native potato low yields.

\section{Materials and Methods}

\section{Study area}

This work was performed over 2017 and 2018 in a region of Aymara culture in the north of the Dept. of La Paz (covering the area of influence of the Humanata community [Municipality of Humanata, Province of Eleodoro Camacho], the Murumamani community area [Municipality of Achacachi, Province of Omasuyos], the Pacollo community area [Municipality of Sorata, Province of Larecaja]) (Table 1) (Fig. 1), and in a region of Quechua culture in the Dept. of Cochabamba (covering the area of influence of the Colomi community [Municipality of Colomi, second section of the Province of Chapare]) (Table 2) (Fig. 1).

In the Aymara region, which has several areas of similar geographical characteristics, native potatoes are cultivated under the traditional 'variety mix' system (Table 1 ). Many native varieties are grown in the Humanata community area $\left(15^{\circ} 27^{\prime} 0^{\prime \prime} \mathrm{S}, 69^{\circ} 7^{\prime} 60^{\prime \prime} \mathrm{W}\right)$ and cultivation is markedly traditional (Iriarte et al. 2009; Coca Morante 2019a). Although, they frequently carry out between 2 and 3 applications with insecticides (cypermethrin) mainly for the Andean potato weevil (Premnotrypes sp) control. The area is home to high and low mountain terrain (mean altitude $4130 \mathrm{~m}$ ); mean annual rainfall is $550 \mathrm{~mm}$. According to the Köppen classification system, the territory has a tundra (ET) 
Table 1 Places in the Aymara region where native potato leaves were sampled for DAS-ELISA virus analyses

\begin{tabular}{|c|c|c|c|c|c|c|}
\hline Locality & Province & Department & Year & Altitude (m) & Variety (Native name) & Species \\
\hline Humanta, Villa T'ikata & Camacho & $\mathrm{La} \mathrm{Paz}$ & 2017 & 4250 & Sani Imilla, & Solanum andigena \\
\hline Pampajasi & Camacho & $\mathrm{LaPaz}$ & 2017 & 4250 & Ch'uju sak'ampaya & Solanum andigena \\
\hline Quillihuyu & Camacho & $\mathrm{La} \mathrm{Paz}$ & 2017 & 4250 & Jank'o Imilla & Solanum andigena \\
\hline Jichuiri Mojsa Huma & Camacho & $\mathrm{LaPaz}$ & 2017 & 4250 & Pichuya & Solanum andigena \\
\hline Villa T'ikata & Camacho & $\mathrm{LaPaz}$ & 2017 & 4250 & Ch'iar Imilla & Solanum andigena \\
\hline Humanata "A" & Camacho & La Paz & 2017 & 4235 & Mixed varieties & Solanum spp. \\
\hline Jajaya & Camacho & $\mathrm{LaPaz}$ & 2017 & 4235 & Mixed varieties & Solanum spp. \\
\hline Jichuiri T'icani & Camacho & $\mathrm{La} \mathrm{Paz}$ & 2017 & 4250 & Mixed varieties & Solanum spp. \\
\hline Carani & Camacho & $\mathrm{La} \mathrm{Paz}$ & 2017 & 4250 & Mixed varieties & Solanum spp. \\
\hline Janko marca & Camacho & $\mathrm{La} \mathrm{Paz}$ & 2017 & 4250 & Mixed varieties & Solanum spp. \\
\hline Tahuarcota & Camacho & $\mathrm{La} \mathrm{Paz}$ & 2018 & 4250 & Mixed varieties & Solanum spp. \\
\hline Ch'ajana & Camacho & $\mathrm{La} \mathrm{Paz}$ & 2018 & 4210 & Ch'iar Imilla & Solanum andigena \\
\hline Cancanani & Camacho & $\mathrm{La} \mathrm{Paz}$ & 2018 & 4210 & Jank'o Imilla & Solanum andigena \\
\hline Jajaya & Camacho & $\mathrm{La} \mathrm{Paz}$ & 2018 & 4210 & Mixed varieties & Solanum spp. \\
\hline Quillihuyu & Camacho & $\mathrm{La} \mathrm{Paz}$ & 2018 & 4250 & Jank'o Imilla & Solanum andigena \\
\hline Tahuarcota & Camacho & $\mathrm{La} \mathrm{Paz}$ & 2018 & 4250 & Ch'uju & Solanum andigena \\
\hline S. Machaca & Camacho & $\mathrm{La} \mathrm{Paz}$ & 2018 & 4250 & Wila Sak'ampaya & Solanum andigena \\
\hline Villa T'ikata & Camacho & $\mathrm{La} \mathrm{Paz}$ & 2018 & 4250 & Ch'iar Imilla & Solanum andigena \\
\hline Stgo Tirajahua-A & Camacho & $\mathrm{La} \mathrm{Paz}$ & 2018 & 4250 & Jank'o pala & Solanum andigena \\
\hline Sgto Tirajahua-B & Camacho & $\mathrm{La} \mathrm{Paz}$ & 2018 & 4200 & $\mathrm{nn}$ & Solanum andigena \\
\hline Llasayara & Omasuyos & $\mathrm{La} \mathrm{Paz}$ & 2017 & 4050 & Ch'iar Imilla & Solanum andigena \\
\hline Llasayara & Omasuyos & $\mathrm{La} \mathrm{Paz}$ & 2017 & 4050 & Huaych'a nativa & Solanum andigena \\
\hline Llasayara & Omasuyos & $\mathrm{La} \mathrm{Paz}$ & 2017 & 4050 & Ch'iar Qhati & Solanum andigena \\
\hline Murumamani & Omasuyos & $\mathrm{La} \mathrm{Paz}$ & 2017 & 4290 & Pala & Solanum andigena \\
\hline Murumamani & Omasuyos & $\mathrm{La} \mathrm{Paz}$ & 2017 & 4290 & Huaych'a & Solanum andigena \\
\hline Murumamani & Omasuyos & $\mathrm{La} \mathrm{Paz}$ & 2017 & 4290 & Sak'ampaya & Solanum andigena \\
\hline Murumamani & Omasuyos & $\mathrm{La} \mathrm{Paz}$ & 2017 & 4290 & Morok Luk'y & Solanum x juzepzukii \\
\hline Murumamani & Omasuyos & $\mathrm{La} \mathrm{Paz}$ & 2017 & 4290 & Ch'iar Huacalajra & Solanum andigena \\
\hline Llasayara & Omasuyos & $\mathrm{La} \mathrm{Paz}$ & 2018 & 4050 & Pukamama & Solanum andigena \\
\hline Llasayara & Omasuyos & $\mathrm{La} \mathrm{Paz}$ & 2018 & 4050 & Jank'o Imilla & Solanum andigena \\
\hline Llasayara & Omasuyos & $\mathrm{La} \mathrm{Paz}$ & 2018 & 4050 & Surimana & Solanum andigena \\
\hline Llasayara & Omasuyos & $\mathrm{La} \mathrm{Paz}$ & 2018 & 4050 & Sani Imilla & Solanum andigena \\
\hline Llasayara & Omasuyos & $\mathrm{La} \mathrm{Paz}$ & 2018 & 4050 & $\mathrm{nn}$ & Solanum andigena \\
\hline Pacollo & Larecaja & $\mathrm{La} \mathrm{Paz}$ & 2018 & 4180 & Pala & Solanum andigena \\
\hline Pacollo & Larecaja & $\mathrm{La} \mathrm{Paz}$ & 2018 & 4180 & Polo & Solanum andigena \\
\hline
\end{tabular}

Years 2017 and 2018

climate, i.e. it is cold and wet during summer (December to March). The main crops are forage, potatoes and root crops (SEDALP 2020). A large proportion of the potatoes grown in the neighbouring centres of Murumamani, Llasaraya and Pacollo (15 $\left.52^{\prime} 15.6^{\prime \prime} \mathrm{S}, 68^{\circ} 37^{\prime} 16.3^{\prime \prime} \mathrm{W}\right)$, which are also close to Achacachi, are of improved varieties. Indeed, native potatoes are being lost here (Coca Morante 2019b). All these centres lie on the road from Achacachi to Sorata (in the Province of Larecaja) (mean altitude $4150 \mathrm{~m}$ ) close to Mt. Illampu (6560 m) in Bolivia's Cordillera Oriental range. All have a cold, wet climate; mean annual rainfall is $650 \mathrm{~mm}$ (Fig. 1).
The Quechua region is different in several aspects from the Aymara region, for example, cultivated varieties, use of technology, access to the market, geographical and climatic characteristics, etc. It covers the area of influence of Colomi municipality, which includes the communities of Pico central, P'alta loma and Rodeo ( $16^{\circ} 56^{\prime} 02^{\prime \prime}-17^{\circ} 23^{\prime} 34^{\prime \prime} \mathrm{S}, 65^{\circ}$ $33^{\prime} 15^{\prime \prime}-66^{\circ} 20^{\prime} 34^{\prime \prime} \mathrm{W}$; mean altitude $3400 \mathrm{~m}$ ); here, potatoes are grown in monovarietal plots (Table 2 ). The region lies some $40 \mathrm{~km}$ from the city of Cochabamba, and therefore has easier access to improved seed (certified and resistant to Phytophthora infestans). Nonetheless, it is considered an microcentre of potato genetic diversity (MPGD) for native 

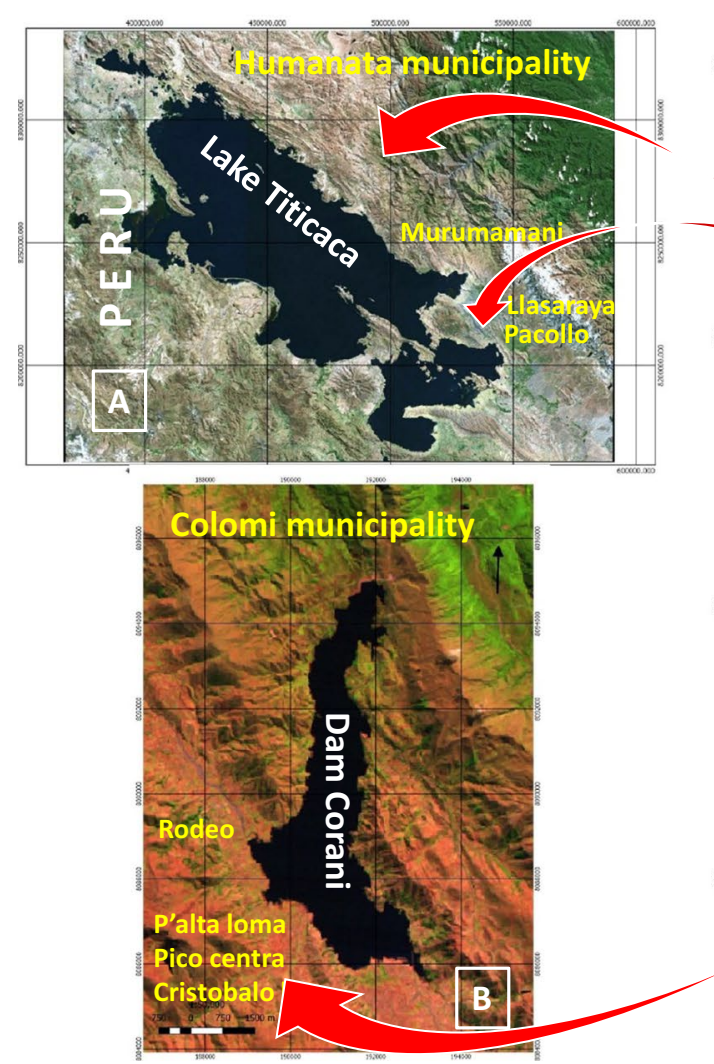

Fig. 1 Location of potato genetic diversity microcentres. A Area of influence of the Humanata Municipality (Aymara region), Province of Eleodoro Camacho, Department of La Paz; B Area of influence of

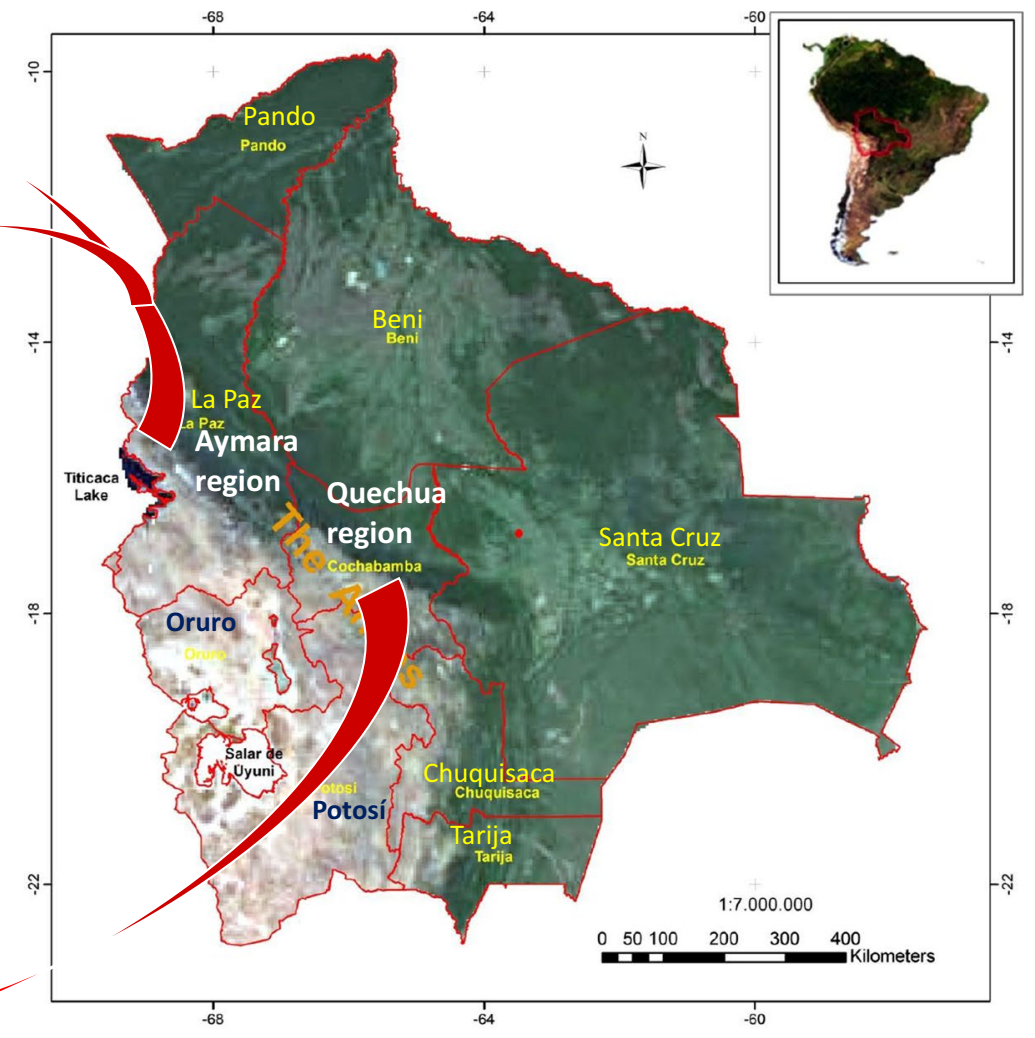

the Colomi Municipality influence area (Quechua region), Province of Chapare, Department of Cochabamba, Bolivia. (Maps produced by CISTEL, Engineering Department, FCAyP-UMSS)

region per 2017 year]) were taken from the mid-plant area during flowering (January-February) (Tables 1 and 2). Samples were placed in BIOREBA Universal $12 \times 15 \mathrm{~cm}$ extraction bags following the manufacturer's protocol to avoid contamination. These bags were then placed in an insulated box containing ice and taken to the laboratory. Samples were collected in 2017 in the Quechua region, and in 2017 and 2018 in the Aymara region (in the latter region the search for viral infections was extended to further plots during 2018).

\section{Serological Test Virus and Analysis}

The presence of PVY, PLRV, PVX, APLV and APMoV in leaf samples was detected using Double-Antibody Sandwich-ELISA kits from BIOREBA (these kits employ polyclonal antibodies for antigen capture and visualization [conjugated with alkaline phosphatase]), according to the manufacturer's instructions. In each assay / plate a positive and negative control of the DAS-ELISA test and a lyophilized sample of virus-free potato tissue was used (BIOREBA). Colorimetry was performed using a Multiscan device from Labsystem. The results DAS-ELISA tests were analysed from the statistical procedure described by type plant per variety (plot) [total $n=51$ leaflets in Quechua 
Table 2 Places in the Quechua region where native potato leaves were sampled for DAS-ELISA virus analyses

\begin{tabular}{|c|c|c|c|c|c|c|}
\hline Locality & Province & Department & Year & Altitude (m) & Variety (Native name) & Specie \\
\hline Cristobal & Chapare & Cochabamba & 2917 & 4093 & Yana Qoyllu & Solanum stenotomum \\
\hline Cristobal & Chapare & Cochabamba & 2017 & 4093 & Puka Ñujcha & Solanum stenotomum \\
\hline Cristobal & Chapare & Cochabamba & 2017 & 4093 & Candelero & Solanum stenotomum \\
\hline Cristobal & Chapare & Cochabamba & 2017 & 4093 & Sak'ampaya & Solanum tuberosum subsp andigena \\
\hline P'alta loma & Chapare & Cochabamba & 2017 & 3601 & Yana Qoyllu & Solanum stenotomum \\
\hline P'alta loma & Chapare & Cochabamba & 2017 & 3601 & Phureja & Solanum phureja \\
\hline P'alta loma & Chapare & Cochabamba & 2017 & 3601 & Pinta boca & Solanum stenotomum \\
\hline P'alta loma & Chapare & Cochabamba & 2017 & 3601 & Zapallo & Solanum goniocalix \\
\hline P'alta loma & Chapare & Cochabamba & 2017 & 3601 & Puka Ñujch’a & Solanum stenotomum \\
\hline P'alta loma & Chapare & Cochabamba & 2017 & 3601 & Puma Maqui & Solanum stenotomum \\
\hline P'alta loma & Chapare & Cochabamba & 2017 & 3601 & Pitu Huayagha & Solanum stenotomum \\
\hline P'alta loma & Chapare & Cochabamba & 2017 & 3601 & File & Solanum $s p$ \\
\hline P'alta loma & Chapare & Cochabamba & 2017 & 3601 & Mono maqui & Solanum tuberosum subsp andigena \\
\hline P'alta loma & Chapare & Cochabamba & 2017 & 3601 & Sak'ampaya & Solanum tuberosum subsp andigena \\
\hline P'alta loma & Chapare & Cochabamba & 2017 & 3601 & Puka mama & Solanum spp \\
\hline P'alta loma & Chapare & Cochabamba & 2017 & 3601 & Imilla Blanca & Solanum tuberosum subsp andigena \\
\hline P'alta loma & Chapare & Cochabamba & 2017 & 3601 & Huaych'a & Solanum tuberosum subsp andigena \\
\hline P'alta loma & Chapare & Cochabamba & 2017 & 3601 & Candelero & Solanum stenotomum \\
\hline Pico central & Chapare & Cochabamba & 2017 & 3719 & Phureja & Solanum phureja \\
\hline Pico central & Chapare & Cochabamba & 2017 & 3719 & Huaych'a & Solanum tuberosum subsp andigena \\
\hline Pico central & Chapare & Cochabamba & 2017 & 3719 & Sak'ampaya & Solanum tuberosum subsp andigena \\
\hline Pico central & Chapare & Cochabamba & 2017 & 3719 & Puka Qoyllu & Solanum stenotomum \\
\hline Pico central & Chapare & Cochabamba & 2017 & 3719 & Yana Imilla & Solanum tuberosum subsp andigena \\
\hline Pico central & Chapare & Cochabamba & 2017 & 3719 & Pinta boca & Solanum stenotomum \\
\hline Pico central & Chapare & Cochabamba & 2017 & 3719 & Pitu Huayagha & Solanum stenotomum \\
\hline Pico central & Chapare & Cochabamba & 2017 & 3719 & Nujch'a & Solanum stenotomum \\
\hline Pico central & Chapare & Cochabamba & 2017 & 3719 & Mono maqui & Solanum tuberosum subsp andigena \\
\hline Pico central & Chapare & Cochabamba & 2017 & 3719 & Candelero & Solanum stenotomumo \\
\hline Pico central & Chapare & Cochabamba & 2017 & 3719 & Yana Qoyllu & Solanum stenotomum \\
\hline Pico central & Chapare & Cochabamba & 2017 & 3719 & Puka Ñujch’a & Solanum stenotomum \\
\hline Pico central & Chapare & Cochabamba & 2017 & 3875 & Candelero & Solanum stenotomum \\
\hline Pico central & Chapare & Cochabamba & 2017 & 3875 & Runa & Solanum tuberosum subsp andigena \\
\hline Pico central & Chapare & Cochabamba & 2017 & 3875 & Imilla Blanca & Solanum tuberosum subsp andigena \\
\hline Pico central & Chapare & Cochabamba & 2017 & 3875 & Puka Qoyllu & Solanum stenotomum \\
\hline Rodeo & Chapare & Cochabamba & 2017 & 3706 & Imilla Blanca & Solanum tuberosum subsp andigena \\
\hline Rodeo & Chapare & Cochabamba & 2017 & 3706 & Uturunku & Solanum spp \\
\hline Rodeo & Chapare & Cochabamba & 2017 & 3706 & Pinta boca & Solanum stenotomum \\
\hline
\end{tabular}

Year: 2017

BIOREBA serological company that uses a frequency distribution histogram. Frequency histograms were produced in order to define cut-offs and thus allow the detection of false negatives and positives. Cut-offs were determined using the formula mean $+3 s \times 1.1$, where 'mean' refers to the mean values of negative control and 's' to its standard deviation, as recommended by the kit manufacturer. The incidence (percentage) of viral infection was determined as the number of positive samples/total number of samples $\times 100$.

\section{Potato Yield (t.ha ${ }^{-1}$ )}

Potato yield estimates were made during April and May in each locality. The evaluated plots were small between 500 and $1500 \mathrm{~m}^{2}$. Three $5 \mathrm{~m}$-long rows, with $0.7 \mathrm{~m}$ between rows, were harvested in each plot each (performed in triplicate) and the potatoes collected, classified and weighed to obtain the yield $\left(\mathrm{t}^{\mathrm{h} \mathrm{h}^{-1}}{ }^{-1}\right.$. Estimates were made for 2017 only in the Quechua region, but in 2017 and 2018 in the 
Aymara region. To calculate yield averages, the data were analysed using the Minitab 17 statistical package.

\section{Results}

\section{Virus Identification and Mean Incidence}

All viruses-PVX, PVY, APLV, PLRV and APMoV-were detected in the Quechua and the Aymara regions, excepting APMoV in the Aymara region (Fig. 2A and Fig. 3A). The Aymara region has the greater average incidence in the four localities but the highest are in the Humanata and Llasaraya localities (63-92\%) (Fig. 2B); note that the mean incidence compared to the Quechua region is lowest (7-25\%) (Fig. 3B).

\section{Virus Incidence by Region and Locality}

In the Aymara region, the most commonly detected viruses were PVX, PVY and PLRV. PVX was detected in the most extent in both years, while PVY was higher than PVX in 2017 but not in 2018 and PLRV and APLV as a lesser extent (Fig. 2C and 2D). In the Quechua region, PVX, the most common virus, was detected (Fig. 3A); the next most common virus was APLV, followed by PVY and APMoV and PLRV with the extent isolated incidence (figures collected for 2017 only).
Fig. 2 Incidence of viruses in the potato genetic diversity microcentres of the Aymara region. A Virus incidence by year, $\mathbf{B}$ Incidence of virus infection by locality (all viruses together); C Virus incidence, year 2017; D Virus incidence year 2018; E Mixed virus infections year 2017; F Mixed virus infections 2018
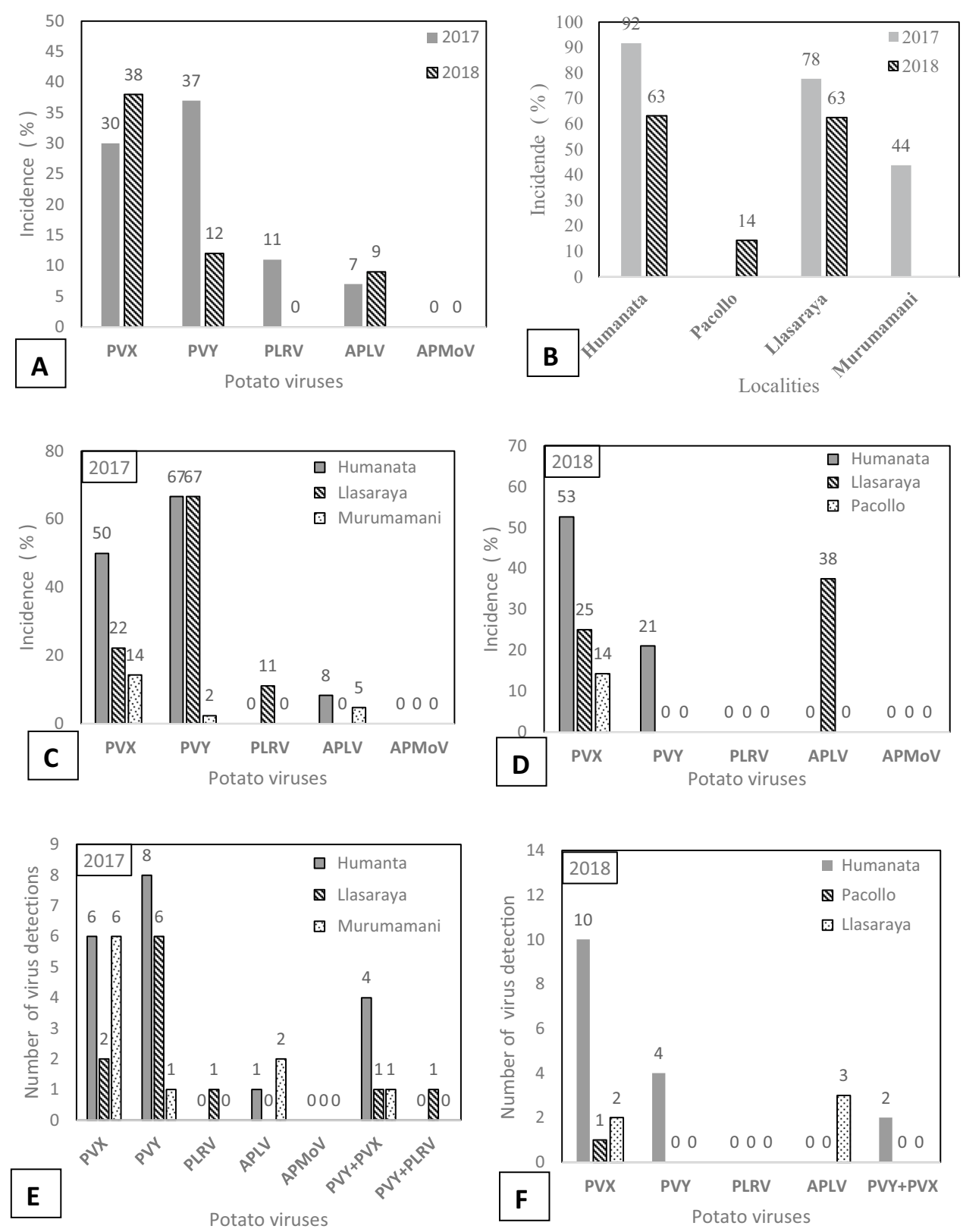
Fig. 3 Incidence of viruses in the potato genetic diversity microcentres of the Quechua region (2017). A Virus incidence by localities; B Incidence of virus infection by locality (all viruses together); $\mathbf{C}$ Virus mixed infections
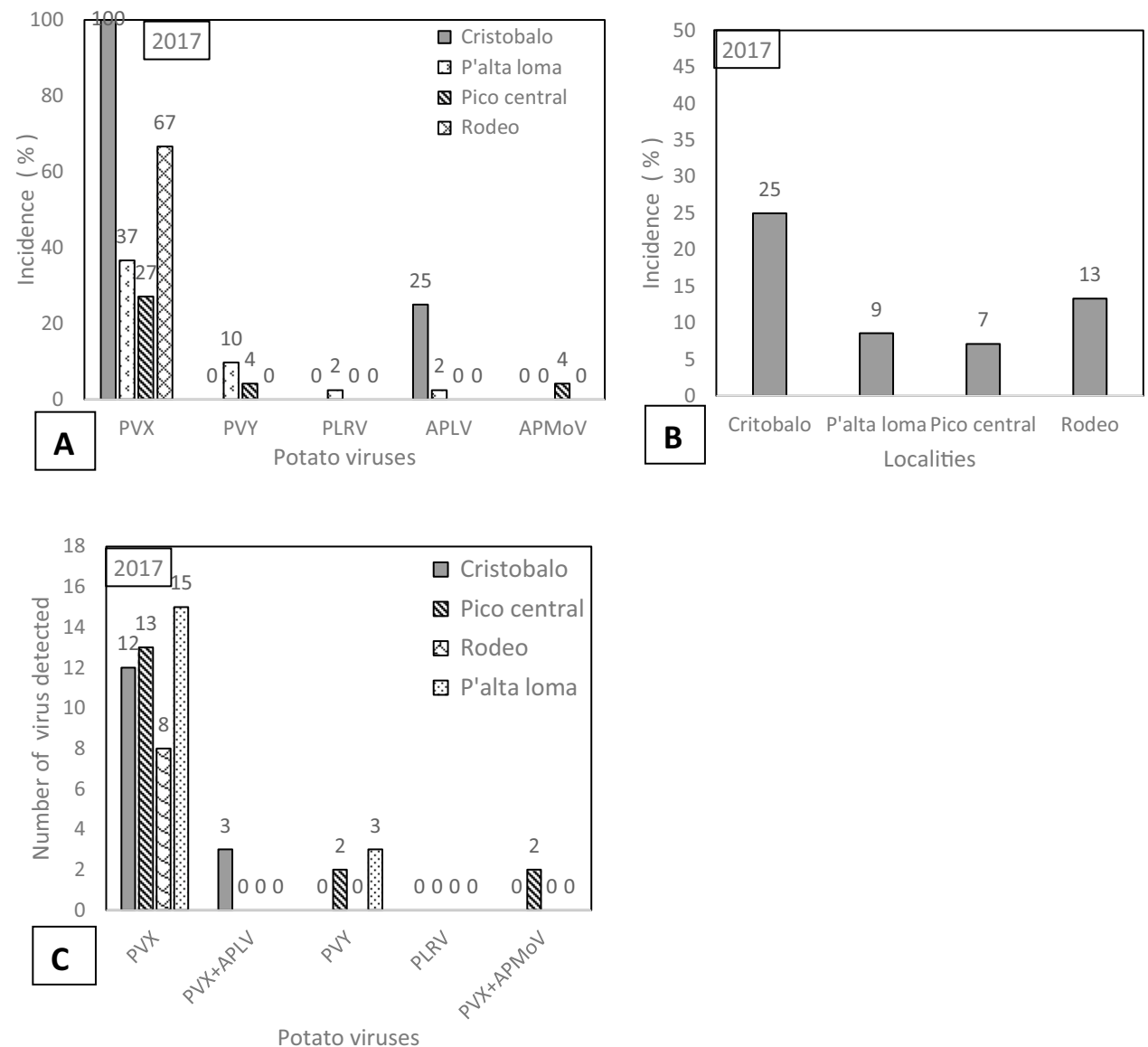

\section{Mixed Viral Infections}

Mixed infections were detected in both the Aymara and Quechua regions (Fig. 2E and F, and Fig. 3C), although they were less common than infection by a single virus. In the Aymara region, the mixed infections detected in 2017 were $\mathrm{PVY}+\mathrm{PVX}$ and PVY + PLRV, and in $2018 \mathrm{PVY}+\mathrm{PVX}$. In the Quechua region they were PVX + APLV and PVX + APMoV (2017 only).

\section{Potato Yields (t.ha ${ }^{-1}$ )}

In the Aymara region, the 2017 yields differed from one place to another (Fig. 3A) $(\mathrm{CV}=34,26 \%)$. The largest yield was recorded in Humanata "A" $\left(14\right.$ t.ha $\left.{ }^{-1}\right)$ and the lowest in Jajaya $\left(4\right.$ t.ha $\left.^{-1}\right)$ but most of yields are between Jichuiri T'icani $\left(6.6\right.$ t.ha $\left.^{-1}\right)$ and Janko marca $\left(10\right.$ t.ha $\left.^{-1}\right)$. Differences were also recorded in 2018, $(\mathrm{CV}=13,62 \%)$ (Fig. 3B), with Tahuarcota $\left(9.8{\mathrm{t} . h a^{-1}}^{-1}\right.$ returning the highest yield and Santiago de Tirajahua $\left(6.6\right.$ t.ha $\left.^{-1}\right)$ the lowest. Few localities were compared in the Quechua region, but more varieties of potato were grown. In P'alta Loma, the 2017 yields differed between potato varieties ( $\mathrm{CV}=24,84 \%)$ (Fig. 4C). The Imilla blanca variety yielded 18 t.ha $^{-1}$ while the Candelero variety 8 t.ha $^{-1}$. In the Quechua region in 2018 (Fig. 3D), yields differed between varieties in the Pico Central area $(\mathrm{CV}=33,73 \%)$ : the Huaych'a variety yielded $25 \mathrm{tha}^{-1}$ while Mono maqui yielded just 6 t.ha ${ }^{-1}$.

\section{Discussion}

PVX, PVY, PLVR, APLV were detected in both the Aymara and Quechua regions, but APMoV only in the Quechua region. The occurrence of those viruses is common in the highlands. Fribourg (1980) reported the most economically important viruses in the Andean territory to be PLRV and PVY, although in the High Andes, PVX, APMoV and APLV were also important. García and Gandarillas (1992) identified PVX, APLV, APMoV and PVY, and less commonly PVS and PLRV, in the Quechuan High Andes region of Cochabamba. In the Sierra Central and Sierra Sur ranges of Peru, Bertschinger et al. (1990), reported viral incidence (in native/improved potatoes) to be: PVX $37-82 \%$, PVS 19-53\%, PLRV and PVY 0.7-6.8\%, Potato yellowing virus (PYV, recorded as SB-22) 39\%, APLV 25\%, and APMoV 3-13\%. In Colombia, García Ruiz et al. (2016), reported a high incidence of PVX in seed potatoes used in Antioquia, 
Fig. 4 Potato yields. A Aymara Region, 2017; B Aymara region, 2018; C Quechua region, P'alta Loma locality (left); D Quechua region, Pico Central locality (right)
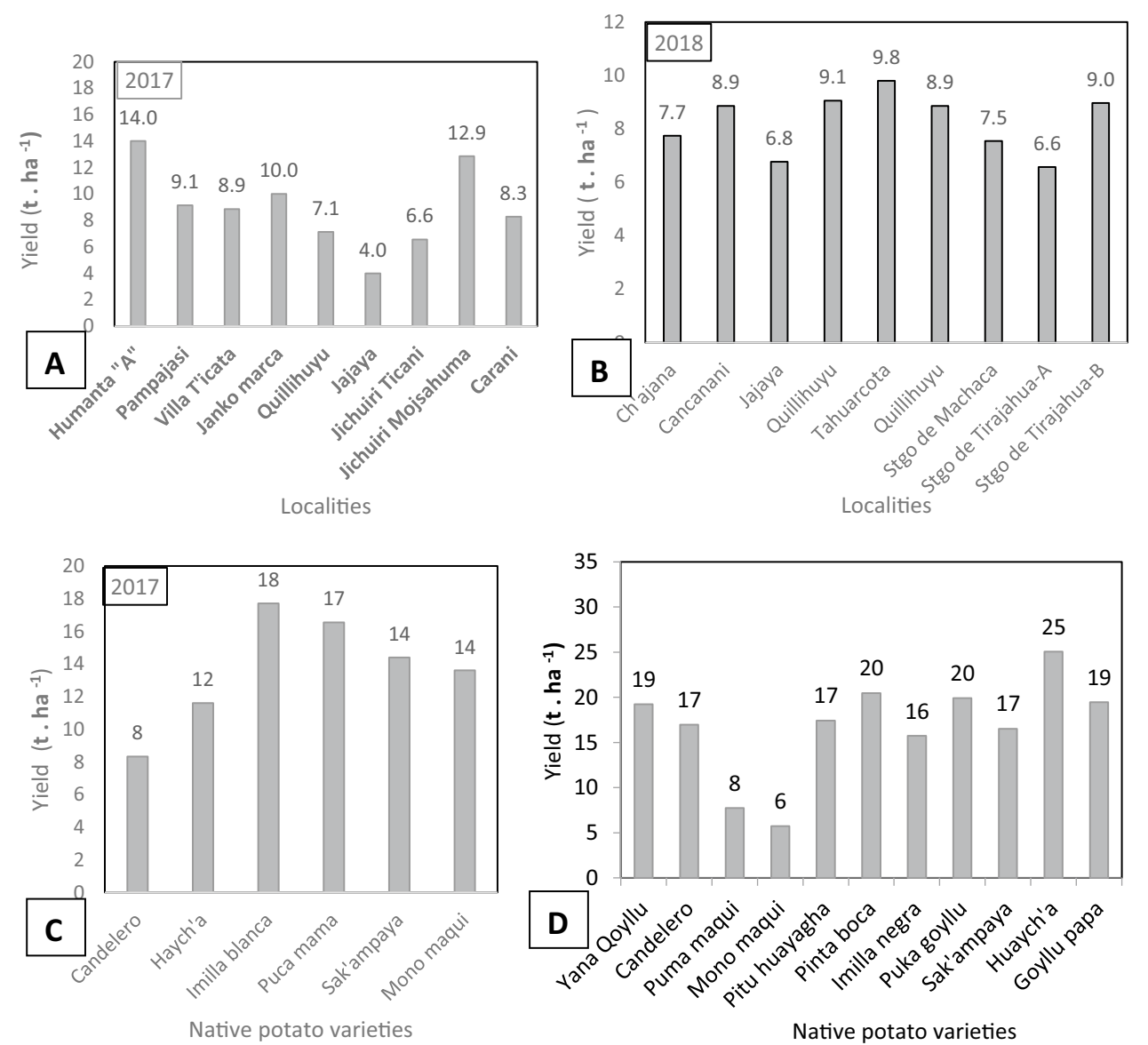

and declared the need to strengthen seed certification programs through RT-qPCR assays. Finally, Kreuze et al. (2020) indicated the most frequently detected viruses in the Andean region to be contact-transmitted, with PVX the most common (incidence $30-82 \%$ ), followed by PVS (20-50\%), APMoV (4-15\%) and APLV (2-6\%). PLRV and PVY, were detected at just $0-5 \%$ in these materials.

In general, although the detected viruses are common, the viral incidence varies in the different agro ecologies (Aymara / Quechua) is apparently related to the local management of potato crops. In the present work, the greatest incidence of viral infection (i.e. irrespective of the specific virus) was seen in the Aymara region, probably because of the traditional use of ancestral-line seed potatoes and agricultural practices however the healthy plants selected in the sampling apparently could be of the refreshed seeds (obtained from exchanges between small holders at local fairs) (Coca Morante 2019b). But, the virus incidence difference between localities, 2017 in relation to 2018, could be due to the different localities sampling in each year. In the Quechua region, most native potato crops are using varieties and better quality of seed tubers. PVX was the most commonly detected virus in both regions, in agreement with that reported by Fribourg (1980), García and
Gandarillas (1992), Bertschinger et al. (1990), Garcia Ruiz et al. (2016) and Kreuze et al. (2020). Nevertheless, it could be associated with some practices too, such as the agrochemicals application (in both regions) related with contact between plants that PVX virus dissemination favouring, PVY was the second most common virus in the Aymara region (4150 m). According to Kreuze et al. (2020), the low incidence of PVY and PLRV in the High Andes of Ecuador is due to the falling number of aphids above $3000 \mathrm{~m}$. However, in the present work, many aphids were seen at altitudes of over $4000 \mathrm{~m}$, perhaps helping to explain the detected incidence of PVY. In the Quechua region, PVY was the third most common virus, which is in line with that described by García and Gandarillas (1992), Bertschinger et al. (1990) and Kreuze et al. (2020). The presence of this virus may also be due to aphids reaching higher altitudes and due to transmission through the seed tubers. Certainly, it has been reported different aphid species on native potatoes crops in the high Andean Cochabamba regions (Coca-Salazar, 2018) and transmission due to the traditional handling seed potato tubers in the Andean region. According to Lacomme et al. (2017) Infected seed potato tubers can be an important source of PVY inoculum as they can maintain the virus within a 
crop and enable its spread within daughter growing crops and to other potato crops in following seasons.

The present results suggest APLV and PLRV to be of secondary importance. However, APLV was still the most common virus in the Quechua region (in agreement with García and Gandarillas [1992] regarding APLV for the High Andes Quechuan areas of Cochabamba, and it has been historically recorded in Colombia, Peru, Bolivia and Ecuador (Fribourg 1980). According to Kreuze et al. (2020), however, it now appears less commonly in field-grown potatoes in the Andes than when it first detected in the 1970s. In fact, APLV appear as the most common virus in very few more modern reports (Bertschinger et al., 1990; Kreuze et al., 2020). In the present work, PLRV was present but not common in either the Aymara or Quechua region. This agrees with that reported by García and Gandarillas (1992), and partially with that reported by Kreuze et al. (2020) and Bertschinger et al. (1990). However, Fribourg (1980) indicated PLRV to be widely distributed in the mountains of Peru.

APMoV was detected only in the Quechua region, and in low incidence. Fribourg (1980) suggested this virus is not restricted to Peru and Bolivia, and agrees with García and Gandarillas (1992) who indicate it to be important in the High Andes of Cochabamba (Bolivia). In addition, Kreuze et al. (2020) indicates APMoV to infect potato crops in Peru, Argentina and Brazil. The same author indicates that, based on ELISA tests, it seems to have been relatively common and widespread in the past in Peru, while in a recent high throughput sequencing survey it was not commonly encountered. Indeed, the present results support the idea that the virus might be losing importance as a disease-causing agent of field-grown potatoes in the Andean region than when they were first found in the 1970s.

Mixed infections have been reported to have synergistic effects. According to Kreuze et al. (2020), PVX occurs commonly worldwide and causes yield losses of $10-40 \%$ in single infections and is particularly damaging in combination with PVY or PVA. Syller (2012) indicates that mixed infections involving a potyvirus may be particularly damaging. A classic example of the interaction between PVY and PVX is that seen in tobacco plants in which disease symptoms are much severe than those caused by either virus alone, and there is an up-to tenfold increase in the PVX titre compared with single infections. PVY and PLRV also have synergistic interactions in potato; plants thus infected show more severe symptoms than those infected by either virus alone (Syller 2012). The degree of traditional usage of unselected seed tubers in the presently surveyed regions might explain the frequency with which mixed infections were detected. According to Sastry (2013) and Garcia Ruiz et al. (2016), the PVX virus is only transmitted mechanically (i.e. by contact) and through seed tubers. In addition, Kreuze et al. (2020) indicate PVY and PLRV to be transmitted by aphids and differences in the incidence of these viruses between potato crops growing at different altitudes may reflect the abundance of aphid vectors below $3000 \mathrm{~m}$.

Potato yields in both regions (Aymara/Quechua) are different. In the Aymara region, the low yields obtained are similar to those reported by Rodríguez (1954), who recorded yields of 1-5 t.ha ${ }^{-1}$ and 5-7 t.ha ${ }^{-1}$ for potatoes native to the Altiplano de La Paz area. They are also reminiscent of other historically low yields of 5-6 t.ha-1 recorded for Bolivia - the lowest for the entire Andean region and indeed all of Latin America (FAO 2008). These yield figures would appear to be related to viral infections. Rodriguez (1954), records that the low yields of these potatoes native varieties are due to generalized viruses' contamination. Viruses can cause important yield losses, but when in combination with other viruses losses can exceed $80 \%$ (kreuze et al. 2020). PVY, for example, in this region, the 2017 year, had high PVY incidence and low yields (Jajaya, Quillihuyu and JichuiriTicani localities) moreover, there is a higher incidence of mixed infections with PVX and PLRV. PVX is one of the most common viruses affecting potatoes in Colombia and causes losses of 5-20\% worldwide (Gil et al., 2012). However, Quenouille et al. (2013) indicate PVY to be the major viral threat. Both tuber yield and quality are affected, and yield losses can be as high as $80 \%$. The use of farmer saved seed tubers in the Aymara region may facilitate viral transmission. Certainly, PVY is transmitted via the vegetative propagation of infected material, by aphids and, to a lesser extent, by contact (Quenouille et al., 2013), while PVX may be transmitted via the use of seed tubers and contact (García Ruiz et al. (2016). In the Quechua region, the yields were higher, perhaps (among other possibilities) because of the use of certified native seed tubers. Certainly, the incidence of PVX, and especially PVY, was low in this region.

\section{Conclusions}

In conclusion, PVX, PVY, PLRV and APLV were detected in both the Aymara and Quechuan regions surveyed; APMoV was found only in the Quechuan region. The incidence of viral infection in the Aymara region was higher. In both regions, PVX was the virus most commonly detected. PVY was the second most important in the Aymara region, and APLV the second most important in the Quechua region. PLRV and APMoV were of lesser importance. PVY prevalence in both regions could also be attributed to the increased distribution of aphids in high Andean regions over $3000 \mathrm{~m}$. The low yields recorded in the Aymara region may be related to PVY incidence and mixed infections and the use of ancestral-line seed tubers, probably facilitates the viral propagation. In the Quechua region, the higher yields and lower incidence of viruses, including PVX and PVY, 
might reflect the use of better quality native seed tubers and improved agricultural practices. The present work provides an overdue update on the incidence of different viruses that affect potato crops in the Bolivian Andes. Monitoring the incidence of these viruses in different potato varieties over the coming years could provide a much better idea of how to protect potato diversity and improve yields.

Acknowledgements This work was funded by ASDI-UMSS via project PIA.ACC.01, which allows for research into the effects of climate change on Andean tuber crops. The authors thank Segundo Fuentes D., Senior Research Associate at the Crops and Systems Science Division, International Potato Center, Lima, Peru, for suggestions, comments and revision the manuscript. Thanks are also owed to Mario Porres, Martin Fernández and Arminda Galarza (of the P'alta Loma and Kanko communities, Colomi, Cochabamba), Francisco Choque and Rogelio Calle (Humanata community, Province of Camacho, La Paz), Roger Cordero (Pacollo community, Province of Larecaja), and Benedicto Silvestre (Murumamani community, Province of Omasuyos, La Paz), all of whom helped in field work. Henry López Salinas assisted in different parts of this work, and Roberto Calicho, Councillor of the Colomi Municipality assisted in fieldwork. Finally, thanks are due to the Labimed Laboratory, Faculty of Medicine-UMSS for assistance in reading ELISA plates from the virus testing.

\section{Declarations}

Conflict of interest The authors declare that they have no conflict of interest.

Open Access This article is licensed under a Creative Commons Attribution 4.0 International License, which permits use, sharing, adaptation, distribution and reproduction in any medium or format, as long as you give appropriate credit to the original author(s) and the source, provide a link to the Creative Commons licence, and indicate if changes were made. The images or other third party material in this article are included in the article's Creative Commons licence, unless indicated otherwise in a credit line to the material. If material is not included in the article's Creative Commons licence and your intended use is not permitted by statutory regulation or exceeds the permitted use, you will need to obtain permission directly from the copyright holder. To view a copy of this licence, visit http://creativecommons.org/licenses/by/4.0/.

\section{References}

Bertschinger, L., U.C. Scheidegger, K. Luther, O. Pinillos, and A. Hidalgo. 1990. La incidencia de virus de papa en cultivares nativos y mejorados en la sierra peruana. Revista Latinoamericana De La Papa. 3: 62-79.

Bokx, J.A. 1972. Viruses of potatoes and seed potato production. Wageningen, Netherlands. Page three: Centre for Agricultural Publishing and Documentation.

Coca, Morante M. 2019b. Potato production system in the andean region of Bolivia: modern seed potato production, the use of agricultural technology, and genetic erosion. Research \& Reviews: Journal of Agriculture and Allied Sciences. 8: 86-95.

Coca Morante M. 2019a. Impact of pests and diseases of Andean tubers in a context of climate change on domestication centres of Bolivia. Impreso en Talleres Gráficos "Kipus”. Cochabamba, Bolivia. 53 pp.

Daniela, García Ruíz., M.A. Olarte Quintero, P. Gutiérrez Sánchez, and M. Marín Montoya. 2016. Serological and molecular detection of Potato virus X (PVX) in seed potato tubers (Solanum tuberosum L. and Solanum phureja Juz. \& Bukasov) from Antioquia, Colombia. Revista Colombiana De Biotecnología. https://doi.org/10.15446/rev. colomb.biote.v18n1.51389.

Coca Salazar Evelyn, L. 2018. Incidencia de virus en papas nativas en comunidades del municipio de Colomi, Cochabamba. Facultad de Ciencias y Tecnología, Carrera de Biología. Universidad Mayor de San Simón. Tesis Licenciatura en Biología. Cochabamba, Bolivia. $84 \mathrm{pp}$.

FAO. 2008. International year of the potato. http://www.fao.org/potato2008/en/world/latinamerica.html. Accessed 04 August 2021.

Fribourg, C.E. 1980. Historia y Distribución de los Virus de papa en América Latina. Fitopatología. 15 (2): 13-24.

García, W. y A. Gandarillas. 1992. Incidencia virotica en campos de tubérculo-semilla de papa en certificación y campos comerciales. No 21, p. 29-33. Revista de Agricultura. Facultad de Ciencias Agrícolas y Pecuarias, Universidad Mayor de San Simón. Cochabamba, Bolivia.

Gil, J.F., and J.M. Cotes y M. Marín. . 2012. Detección y caracterización molecular del Virus X de la Papa (PVX) en regiones productoras de papa de Colombia. Revista De Protección Vegetal 27 (2): 69-76.

Iriarte, V., B. Condori, D. Parapo y D. Acuña. 2009. Catalogo Etnobotánica de Papas Nativas del Altiplano Norte de La Paz - Bolivia. Fundación Proinpa-Ricerca cooperacione-Instituto nacional de investigación agropecuaria y forestal. La Paz, Bolivia. 142p.

Kreuze, J.F., J.A.C. Souza-Dias, A. Jeevalatha, A.R. Figueira, J.P.T. Valkonen, and R.A.C. Jones. 2020. Chapter 11 Viral Diseases in Potato crop. Pp: 389-429. In: Campos H., Ortiz O. (eds.), The Potato Crop, Its Agricultural, Nutritional and Social Contribution to Humankind. Springer Nature, Switzerland AG. Pp:518.

Lacomme, Ch., E. Jacquot. 2017. Chapter 1 General Characteristics of Potato virus Y (PVY) and Its Impact on Potato Production, An Overview. Pp: 1-19. In: Christophe Lacomme, Laurent Glais, Dirk U Bellstedt, Brice Dupuis Alexander, V. Karasev, Emmanuel Jacquot (eds.), Potato virus Y: biodiversity, pathogenicity, epidemiology and management, DOI https://doi.org/10.1007/ 978-3-319-58860-5_1

Lacomme Ch., Pickup J., Fox A., Glais L., Dupuis B., Steinger T., Rolot J-L, Jari P.T. Valkonen, Kerstin Kruger, Xianzhou Nie, Spela Modic, Natasa Mehle, Maja Ravnikar, and Maurice Hullé. 2017. Transmission and Epidemiology of Potato virus Y. pp: 149-176. In: In: Christophe Lacomme, Laurent Glais, Dirk U Bellstedt, Brice Dupuis Alexander, V. Karasev , Emmanuel Jacquot (eds.), Potato virus Y: biodiversity, pathogenicity, epidemiology and management, DOI https://doi.org/10.1007/978-3-319-58860-5_1

PDM. 2002. Plan de desarrollo municipal ajustado 2003 - 2007. Gobierno Municipal de Colomi segunda sección Provincia Chapare. Viceministerio de Planificación Estratégica y Participación Popular Programa de Desarrollo de Comunidades Rurales PDCR-II. 2002. Cochabamba, Bolivia.

Quenouille, J., N. Vassilakos, and B. Moury. 2013. Potato virus Y: A major crop pathogen that has provided major insights into the evolution of viral pathogenicity. Molecular Plant Pathology 14 (5): 439-452. https://doi.org/10.1111/mpp.12024.

Rodríguez, W. 1954. Colección de ecotipos y especies indígenas de papa. Proyecto A-II.C-1, Subproyecto A-II-C-1a. Informe técnico Estación Experimental del Altiplano (Belén) 1953-54. Servicio Agrícola Interamericano. La Paz, Bolivia.

Sastry, K.S. 2013. Seed-borne Plant Virus Diseases, 24. India. p: Springer.

Scholthof karen-beth, G., S. Adkins, H. Czosnek, P. Palukaitis, E. Jacquot, T. Hohn, Barbara Hohn, K. Saunders, T. Candresse, P. Ahlquist, Cynthia Hemenway and G.D. Foster. . 2011. Review: Top 10 plant viruses in molecular plant pathology. Molecular Plant Pathology 12 (9): 938-954. https://doi.org/10.1111/J.1364-3703.2011.00752.X.

SEDALP. 2020. Sistema de información municipal regionalizado del departamento de La Paz. http://autonomias.gobernacionlapaz.com/ sim/fichamunicipal.php?mn=41. Accessed Nov 2020. 
Syller, J. 2012. Facilitative and antagonistic interactions between plant viruses in mixed infections. Molecular Plant Pathology 13 (2): 204-216. https://doi.org/10.1111/J.1364-3703.2011.00734.X.

Terrazas, F., A. Guidi, X. Cadima, R. Gonzales, E. Chávez, J. Almanza, M. Salazar and J. P. Baudoin. 2005. Conservación in situ y valoración de las papas nativas en el microcentro de diversidad genética de candelaria, Cochabamba-Bolivia. Agrociencia. Vol. IX $\mathrm{N}^{\circ} 1$ y No 2 pág. 135 - 146. In: Simposio de Recursos Genéticos para América Latina y el Caribe. 23 al 25 de noviembre de 2005. Montevideo, Uruguay.

\section{Authors and Affiliations}

\section{Mario Coca Morante ${ }^{1} \cdot$ Evelyn Coca Salazar $^{2} \cdot$ Javier Burgos Villegas $^{3} \cdot$ Nelson Tapia Ponce $^{4}$}

1 Laboratorio de Fitopatología, Departamento de Fitotecnia, Facultad de Ciencias Agrícolas Y Pecuarias, Universidad Mayor de San Simón, Cochabamba, Bolivia

2 Facultad de Ciencias Y Tecnología, Universidad Mayor de San Simón, Cochabamba, Bolivia

3 Centro de Investigación en Sistemas de Teledetección (CISTEL), Departamento de Ingeniería, Facultad de Ciencias
Agrícolas Y Pecuarias, Universidad Mayor de San Simón, Cochabamba, Bolivia

4 Facultad de Ciencias Agrícolas Y Pecuarias, Agroecología Universidad Cochabamba (AGRUCO), Universidad Mayor de San Simón, Cochabamba, Bolivia 